\title{
Makna Sebuah Perjumpaan
}

$\begin{array}{ll}\text { Judul } & \text { : Pastor Katolik di UIN Syarif Hidayatullah } \\ \text { Penulis } & \text { : Greg Soetomo, SJ. } \\ \text { Penerbit } & \text { : OBOR } \\ \text { Cetakan } & \text { : Juli } 2017 \\ \text { ISBN } & : 978-979-565-803-0 \\ \text { Tebal } & : x i x+354\end{array}$

\section{Oleh Marz Wera}

Hari-hari ini Islam selalu dipandang sebagai puing-puing reruntuhan dan identik dengan berbagai tindakan destruktif. Perjalanan keislaman selalu dilihat penuh tragedi. Pada posisi inilah sejarah didistorsi menjadi dilematis. Hanya karena ulah beberapa oknum yang salah menafsirkan doktrin agama, dengan alibi tindakan apologetis.

Hasil riset humaniora yang sangat kompeherensif dari Greg Soetomo lahir mengubah perspektif ini. Baginya, agama itu sebuah realitas. Sebagai realitas, akal budi dirangsang untuk masuk ke tataran refleksi intelektual. Umat beragama dituntut untuk merefleksikan iman secara rasional. Nah, rasionalitas ini tumbuh dalam kehidupan nyata. karena realitas hidup beragama selalu terkait dengan situasi kultural-religius, soal fakta keberagaman agama, budaya dan keyakinan.

Greg Soetomo mengambil posisi bagaimana berteologi secara Katolik, tapi kontekstual. Ia berani untuk beranjak dari karakter magis-religius menjadi religius-rasional. Dimensi pengalaman religiusnya didesak untuk keluar meniti pemahaman rasional dalam suasana "perjumpaan" sekaligus memaknai pengalaman iman agar bertumbuh secara inklusif.

"Perjumpaan", ini penting sebagai lokus untuk melihat sesama, sebagai wahana yang menghidupkan. Ketika "perjumpaan" terjadi maka setiap pribadi akan sadar akan arti 
penting kehadiran orang lain baginya, dan kehadiran setiap orang memberi makna bagi sesamanya.

Perjumpaan ini juga sebagai ruang dialog antar iman dalam membingkai kecemasan, kebencian, amarah, dan banjir emosi antara sesama umat beragama. Selama ini, kurang lebih dua tahun belakangan energi bangsa ini habis karena kehidupan umat beragama dalam ambang keresahan yang menyeramkan. Perjumpaan selalu melahirkan spontanitas yang penuh belas kasih, damai, cinta pada sesama dan rasa peduli. Karena naluri moral dalam agama serta empatinya dirangsang secara nyata dalam peristiwa hidupnya.

Artinya agama jangan hanya berkutat pada aspek formalitas, tapi bagaimana spirit keterlibatan umat. Ekspresi keberimanan harus sejalan dengan ajaran. Hidup beragama harus diekspresikan dalam ruang hidup bersama, sebagai simpul kesatuan dari anekaragam identitas untuk saling mewarnai. Simpul kesatuan inilah yang akan direkatkan lewat perjumpaan-perjumpaan hidup, dan itulah absolutnya nilai hidup dalam beragama.

\section{Menelusuri pengalaman iman}

Hakekat agama tidak bisa dipisahkan dari ruang kebudayaan secara global dan universal. Dalam konteks itu ada tiga dimensi penting yang menjadi pedoman dalam melihat dan memahami perbedaan iman beragama.

Pertama, dimensi kultural. Bagaimana berteologi dari konteks budaya citarasa yang hidup dan bertumbuh. Kedua, dimensi sosial. Keterlibatan kita dalam meleburkan diri sesuai dengan iman agama masing-masing, melihat sesama manusia yang saling membutuhkan. Ketiga, religius. Soal teologi lintas agama, penghargaan perbedaan identitas, pengakuan pada realitas hakiki, apresiasi secara inklusif.

Bagi Greg Soetomo, pengalaman belajar empat tahun di UIN Syarif Hidayatullah Jakarta menjadi bukti dialogisnya dan keberanian untuk berteologi ke ranah praksis sekaligus mendorong sesama terlibat. Banyak orang gagal paham dalam membedakan antara prinsip umum dengan respons secara spesifik terhadap tantangan historis partikular dan konkret. Baginya, "Orang Katolik adalah peziarah. Dialog dengan mereka yang 
berbeda iman dan agama adalah bagian dari peziarahan lintas-kepercayaan untuk menemukan Tuhan juga."

Hidup beragama jangan hanya bicara soal surga dan neraka, tapi bagaimana membangun dunia yang hidup dengan damai dan tali kasih. Suasana "perjumpaan" harus bertransformasi menjadi interpersonal. Merayakan perbedaan dan keanekaragaman harus menjadi pemandangan dan pengalaman konkret. Pengalaman nyata memberi ruang berbagi pengalaman iman yang menggerakkan orang untuk sadar dan terlibat. Proses dialektis sekaligus dialogis.

Bagi Hegel, lewat proses dialektis, sejarah menjadi peristiwa tempat komunitas manusia yang merupakan representasi pandangan dunia dan konsepsi kehidupan bergerak menjadi semakin rasional dan sadar diri. Karena sejarah manusia berjalan seiring dengan kemajuan kesadaran untuk meraih kebebasan. Dalam hal itu perjalanan sejarah adalah perjalanan roh, idea, kesadaran dan kebebasan.

Sejarah manusia adalah sejarah pengakuan atas harga dirinya. Aspek dialogis juga akan diwarnai oleh interaksi simbol-simbol religius dengan realitas. Agama itu selalu tumbuh dan terbentuk dalam setiap perjalanan waktu. Dimensi ini memperlihatkan keberagaman nusantara sekaligus pengalaman sosial-politik yang tersentuh oleh citarasa nilai dan simbol religius nusantara.

\section{Menghidupkan "Tassawuf Sosial”}

Greg Soetomo mengadopsi gagasan Tassawuf Sosial, Hassan Hanafi. Konsep yang memperkuat gagasan Islam nusantara yang berkarakter santun, ramah, dan toleran. Dalam arti hidup beragama bukan melulu sebagai praktik kemenangan ruh, melainkan tindakan partisipatif dan keterlibatan sesama umat dalam peristiwa sosial. Hanafi ingin mengembalikan pemaknaan Tassawuf ini dari vertikal ke horizontal, from upwards to downwards, dari paradigma negatif ke paradigma positif.

Gagasan Tassawuf sosialnya dirumuskan dalam tiga fase. Pertama, moral. Tassawuf sejak awal hanya pada aspek mengolah jiwa, kehendak, nilai-nilai, kemurnian hati, lewat berbagai latihan rohani. Sementara tantangan hari-hari ini menuntut lebih dari itu. Melampuinya adalah persoalan nyata dalam hidup sosial bersama. Kedua, etis-psikologis. 
Bagaimana mendorong nilai pasif ke nilai aktif dan dari tahapan psikologis ke perjuangan sosial. Ketiga, metafisis. soal rekonstruksi sosial yang dirumuskan dalam tiga dimensi: dari vertikal ke horisontal, dari langkah moral ke periode sejarah, dari dunia "Sana" ke dunia "sini."

Sajian buku ini sangat komperehensif, kritis dan kedalaman refleksi pengalaman belajar yang memang disajikan khusus untuk kalangan yang punya formasi intelektual memadai, bukan untuk umum karena bahasan yang sangat ilmiah-teoritis. Lebih dari itu, buku ini merupakan warna baru yang perlu dipelajari sebagai khazanah intelektual lintas agama, lantas semangat keberagaman.

Terlepas dari itu, agama dalam peradaban manusia adalah "sumur nilai" tempat orang menimbah kebijaksanaan, ruang untuk merajut persaudaraan, punya muatan etis bagi kebajikan bersama. Sebagaimana Tassawuf Sosial, Hanafi. Hidup beragama bergeser dari seragam menjadi anekaragam, dari satu menjadi banyak, dari kesatuan menjadi keterpecahan yang saling mewarnai.

Tentunya "sumur nilai" ini harus terus hidup dalam ingatan bersama, tidak boleh berakhir dengan berlalunya masa lalu dan masa sekarang ini, itulah makna sebuah "perjumpaan" yang tersimpul dalam harmoninya nada dasar bangsa kita yaitu Pancasila.

\section{Tentang Penulis:}

Marz Wera - Menjabat Pengurus Pusat PMKRI 2018-2020. Founder komunitas Pelangi Nusantara, PENA Institut, dan MarzArtDeco studio. Menulis di Kompas, Pikiran Rakyat, Majalah Hidup, Sesawi.net, Geotimes dll. Penulis berkonsentrasi pada tema-tema dialog, resolusi konflik, teknokultur, dan komunikasi digital. 